\title{
Application of Project - based Learning in the Curriculum of Foreign Trade English Correspondence
}

\author{
Yu Zhang ${ }^{1, a^{*}}$ \\ ${ }^{1}$ The Engineering and Technical College of Chengdu University of Technology, Leshan, China \\ a512316180@qq.com
}

\begin{abstract}
Keywords: Project-based learning; Foreign trade correspondence; Teaching mode design
\end{abstract}
\begin{abstract}
Project-based learning is a system of teaching and learning methodology which consists of an array of activities that are based on the specific project setting up under the guidance of the teacher, in case that the students participate actively in the settlement of the project, so as to complete a series of teaching and learning objectives. In this paper, the basic concepts and methods of project-based learning and teaching are introduced to apply for the foreign trade correspondence writing. By simulating the real circumstance of foreign trade practice, setting up foreign trade project case, indoctrinating professional knowledge of foreign trade business, and dynamically mobilizing students' autonomous learning ability, the teacher tries to integrate the project-based learning method and the foreign trade correspondence course, and explore how to utilize the project-based teaching method to improve students' foreign trade English correspondence writing ability and cultivate students' communication competence in different foreign trade business environment.
\end{abstract}

\section{Introduction}

With China's economic development and the development of foreign trade worldwide, the function of English business correspondence in foreign trade areas becomes more and more important. As a professional core course for English majors, the English business correspondence has generally set up in many colleges and universities for its strong practical means and application. Foreign Trade English Correspondence integrates international trade courses with English business letter writing [1] It covers all the processes of import and export in foreign trade practice and includes the following procedures as: establishing business relationship, inquiry, offer, counter-offer, order, payment, packing, shipment, insurance, complaint and claim, and dispute settlement. In the practice of import and export business, the English correspondence writing and business knowledge of foreign trade is closely linked. In the course of teaching foreign trade English correspondence, teachers should set the teaching objectives that students should have a comprehensive understanding of foreign trade business knowledge as well as English proficiency in foreign trade business communication skills in writing. Through the course, students not only master the foreign trade business about its commonly used vocabulary and sentence patterns, acquire the writing ability accordingly to the flexible foreign trade business context, but also lay a good foundation for engaging in foreign trade after graduation.

However, in many colleges and universities, the teachers who undertake the foreign trade correspondence teaching, usually apply traditional English teaching methods. By explaining example letters, defining commonly used phrases and expressions, analyzing sentence patterns, drilling some translations, and then allowing students to complete the exercises after class, the teacher is the center of the class, while students passively accept the teacher's explanation. These kind of teacher-oriented methods lack the real business environment of foreign trade, and cannot maximize the learning initiative of students and improve the ability to apply what they have learned in practice; therefore, students will gradually lose their interests in learning this course [2]. In view of the current situation of foreign trade English correspondence teaching, and considering the cultivation of applied students in colleges and universities, teachers should try their best in the teaching practice of foreign trade English correspondence courses, and innovating breakthrough in teaching content, teaching mode and 
teaching methods, while training students about business knowledge, language skills and foreign trade practice in many ways.

\section{Brief Introduction to Project-based Learning Method}

Project-based learning (PBL), which was first put forward by John Dewey [3], has been widely used in various disciplines for more than a century. In the class, the project is to select the real life problems according to the content and interest of the students under the guidance of the teachers. Through collecting and reading the literature materials, and investigating on the spot, the depth of the problem is enhanced, and learners could draw conclusions and submit them in the form of research reports or other products. Project model is not only teaching methods, but also learning methods, the completion of the project is to explore the process of discovery of knowledge and methods to experience the process. The results of the project are the knowledge, skills, and methodologies that students acquire during the learning process. Results can be presented through various forms of presentation, such as written descriptions, oral presentations, and performances.

Project-based learning and teaching model advocates student-oriented in teaching activities, teachers set up projects by simulating real cases, and by using practical and experiential participatory methods, both teachers and students complete a project to achieve teaching objectives. Under the guidance of the teachers, students vividly participate in the project, they can understand the theoretical knowledge behind the project, develop the practical problem-solving ability, and combine the language ability goal and the work ability goal closely. The project teaching method emphasizes on cultivating students' autonomous learning ability. In the project-based learning and teaching, students can not only realize the construction of theoretical knowledge, but also get the practical ability of exercise. By simulating the reality of the business situation, student can engage in the real foreign trade practice; by alter the abstract and boring theoretical teaching into a concrete and vivid practical experiencing, students change from the "passive recipients" into an "active participants" [4]. The combination of theory and practice, and the integration of language knowledge with pragmatic competence is the feature of project-based model. It enhances the students' ability to learn independently, and develops their sense of responsibility. Therefore, the project-based method with its practical significance is widely used in the field of foreign language learning and teaching.

The project-based learning and teaching mode is fit for the foreign trade English correspondence course, by adopting this method, teachers can discard the traditional foreign trade English communication writing teaching mode and make some breakthrough in teaching. In the project mode, students are the center of the classroom and they are the main motivator, while teachers take the role of guide only. Teachers set the case of foreign trade practice, stimulate business situation, guide students through joint participation, cooperative analysis, etc. to solve the project tasks, and complete writing goals of foreign trade English letter. In this process, through the completion of various projects, the teacher designs a wide range of foreign trade topics, in order to exercise the students in different foreign trade business environment in the actual use of English for written communication ability. This project-based learning and teaching method emphasizes the use of linguistic knowledge in the real context and business context, so that students can directly and personally participate in the implementation of foreign trade practical projects. This method fully stimulates students' curiosity, attracts students' attention and enhances students' learning initiative [5]. Under the guidance of the project model, the teacher can achieve the goal of foreign trade English communication by guiding the students to complete the foreign trade projects, and the students can complete the specific project tasks of the foreign trade links through practical means, and develop problem-solving skills to realize the collation and development of business knowledge and the language competence.

\section{Project-Oriented Instructional Design of Foreign Trade English Correspondence Curriculum}

The author takes the English majors of Foreign Languages Department of Engineering and Technical College of Chengdu University of Technology as the object of the course, and applies the PBL 
method in the teaching of foreign trade English correspondence writing course. The teacher will break out the original curriculum content system and reorganize the teaching contents according to the real foreign trade process. Students will be divided into trade parties, while international trade and related contents are set as whole large projects. In the completion of the whole process of import and export business transactions on the basis of the premise of this large project, the large project can further dived into a series of small projects for each trade links, these trade links include: the establishment of business relations, inquiry, orders, payment, packaging, shipping, insurance, complaints and claims and dispute resolution. According to the project model, in-class activities simulating the real work environment in trading company, the students are assigned to the task group and informed the business realm of foreign trade companies. Through the completion of various small projects, students can achieve the final goal of foreign trade correspondence writing tasks. In the course of the project-based learning and teaching model, the theoretical knowledge of the foreign trade English correspondence writing closely links with the actual practices in foreign trade business. According to the teaching objective and the organization content of the project task, the paper takes the foreign trade link of "Establishing and Promoting Business Relations" (Chapter 2) in International Business English Correspondence Course [6] as an example to discuss the curriculum design of the project-based learning and teaching model.

Teachers Set the Case Scenario and Issue the Project Task. In accordance with the premise of international trade buyers and sellers, the whole class of students divided into two sides of foreign trade, respectively, Company A and Company B. Students in Company A are assigned project task as to require the establishing foreign trade and business relations with Company $\mathrm{B}$ and write correspondence accordingly. Students in Company B consider whether accept the inquiry of establishing business relations and give the appropriate response in the reply letter. Through the multi-media teaching equipment, teacher can display the relevant products and production scenes of Company A and Company B as the background of the case in this project, so that students involve in the business environment of Company A and Company B, and experience personally the situation of their own companies, such as the lines of business, production and trade, and so on. Through this process, students take the initiative to think about how to introduce their own companies and establish a business relationship, and they make it clear about their writing tasks.

Students Master the Relevant Foreign Trade Knowledge and Analyze the Project Tasks. In the process of simulating the writing of business relations correspondence, students will need to be familiar with the language features and methodological steps of such correspondence. First of all, teachers can guide students to review the international trade knowledge they have learned, and the students discuss the task and are sensible to the project tasks. For example, students in Company A think about how to introduce their company and products effectively to students in Company B, such as through which channels they know Company B's relevant information and why they want to establish business relations. While students in Company B consider how to respond to students in Company A, such as they agree to establish business relations and show their interests in cooperation. And the teacher can prepare some excellent foreign trade English letters, to show students the content and stylistic features of this kind of correspondence, so that students learn to analyze the text structure, summarize the language features, and then master writing skills for themselves.

Teachers Encourage Students to Write Letters and Students Complete the Project Tasks. After the above discussion and communication on the task of writing correspondence on establishing business relationship, the students have been able to understand the linguistic features and writing steps of such letters and, in the light of the excellent example letters provided by the teachers, students will try to write their own letters, it is so-called "learn by use" [7]. At this point, teacher's going to guide the main objective, and encourage the students to try to write, students can continue to discuss on each other, they can use the learned phrases and sentence patterns, they can also access to the relevant foreign trade information. Teacher can give guidance for students in the appropriate time and encourage them ask questions in the discussion of conceiving the letter. For students who ask 
questions, the teacher can try to allow the students to solve, in order to form a good atmosphere by mutual learning, and collaborate the project task of writing letters in establishing business relations.

Students Demonstrate the Results of the Project and Evaluate the Project Tasks: After the completion of correspondence writing, students on behalf of Company A and Company B should demonstrate their writing results respectively. The teacher and all the students would participate in the discussion; the discussion can be carried out from the aspects of the format of correspondence, the principle of "7Cs", the relevance of the content and the degree of fluency of the sentence. This kind of self-evaluation could help students to sum up business experience, adjust learning strategies, improve the language ability as well as enhance self-confidence, in order to achieve independent learning and independent development [8]. Under the guidance of project-based learning and teaching, in completing the project of establishing business relations, the students are highly involved in group activities, fully mobilized their enthusiasm, and as the staff of Company A and Company B, they try best to contribute their wisdom, inspire the team spirit to completed the task of the project.

\section{Conclusions}

The project-based learning and teaching method has changed the dull and monotonous traditional foreign trade English correspondence writing into an active and pragmatic course. It combines foreign trade business activities with students' writing purpose, and emphasizes on triggering students' real experience feelings and learning motivation which greatly enhances students' interests in this course. The applying of project-based learning and teaching method improves students foreign trade English communication ability, and integrates foreign trade business practice with English language knowledge, and it highlights the characteristics in teaching English for specific purposes. Considering the current situation of the teaching of foreign trade English correspondence and taking into account the cultivation of applied students in colleges and universities, by applying the project model into the course of foreign trade English correspondence and combining the theory with curriculum practice, teachers should explore some breakthroughs in their teaching methods and improve effectively students' language ability and communicative competence.

\section{Acknowledgements}

This research is supported by the Research and Development Fund of Engineering and Technical College of Chengdu University of Technology, project no. C112015002.

\section{References}

[1] Shan Shengjiang. ESP Teaching Research: Theory and Practice. Zhejiang: Zhejiang University Press, 2011.

[2] Wen Jun. Specialized English Teaching and Research. Foreign Language and Foreign Language Teaching Press, 2001.

[3] Beckett, G H and Miller P C. Project-based Second and Foreign Language Education: Past, Present, and Future. Connecticut: Information Age Publishing, 2006: xiv, 3-13, and 24-27.

[4] Hutchinson, Tom and Alan Waters. English for Specific Purposes. Shanghai: Foreign Language Education Press, 2010.

[5] Sheng Meijuan. Business English Writing Business English Correspondence. Huazhong University of Science and Technology Press, 2009.

[6] Qin Yannong, Li Yi. International Business English Correspondence Course. Central South University Press, 2010.

[7] Chen Jianping. A Study of Business English. Zhejiang University Press, 2010. 
[8] Shi Xishu. Research on the Application of Collaborative Learning in College English Based on Project. Foreign Language Education of China, 200 